\title{
TECHNICAL EDUCATION AND INDUSTRIAL TRAINING IN MALTA
}

$\mathrm{T}$

HE development of education in Malta has been very slow and, until recently, technical education almost non-existent and industrial training and apprenticeship schemes confined mainly to H.M. Dockyard.

With the grant of internal self-government in 1921 , an extensive school-building programme commenced, which much improved the position, but not sufficiently to eatch up on the neglect of decades.

Compulsory primary education for all children was not introduced until 1946, when the second period of internal self-government started. But there was insufficient school accommodation, and consequently, in order to cope with the big influx of children, the Government had to introduce a 'two-shift' system by which children received tuition for half-days only.

When the present Government took office in 1955, it immediately gave education top priority in its development plans. It initiated a very large school. building programme, and took over a number of private houses as temporary classrooms. This, together with the recruitment of a large number of temporary teachers, made it possible to abolish the half-time system and provide full-time primary education in 1956 .

The Government was determined that the whole education system should be rebuilt from the bottom upwards, and that particular emphasis should be placed on technical education, thus avoiding the mistakes made in some Colonies where education has tended to develop from the university downwards, and too much emphasis has been placed on the grammar-school type of tuition.

The school-building programme has been astonishingly successful, and great credit must go to the Minister of Education herself-the Hon. Miss Agatha Barbara-for her enthusiasm, drive and exhortations. It is no uncommon sight to see Miss Barbara down on a building site spurring on the architects and workmen to greater efforts for the sake of their children.

So far, thirty primary schools and extension blocks have been completed or are in the course of construction; thirteen are in this year's programme (work on some of them has already begun) and thirteen more will probably be started next year. A technical school for a thousand boys will be completed in a few months time, work has just started on a technical school to house a thousand girls, and a second boys' technical school and a secondary modern type of school for boys will be started next year. Another three years will see the end of the present primary school-building programme.

At the moment only 9 per cent of primary school leavers are able to get any sort of secondary education. The present school-building programme, together with the Government-financed extension to St. Patrick's Technical School, will increase this to 20 per cent : 10 per cent to grammar and secondary modern, and 10 per cent to secondary technical schools.

Nor are the other aspects of development being neglected. The output of the local teachers' training colleges has been stepped up, and teachers are being recruited from overseas for short periods, while Maltese teachers and students are being sent overseas for further education. Unfortunately, the Royal University of Malta has no Education Department.

The hitherto backward state of education has been an important factor contributing to the underdevelopment of the Maltese economy. This has necessitated large-scale emigration, which has deprived the country of its more virile, adventurous and skilled workers, and created an unbalanced population structure: that is, an excess of 20,000 women over men, and fewer and fewer able young working men having to support a proportionately larger number of old people, women and children. This in turn has retarded development and created a feeling of apathy and despair.

There was obviously only one solution : to make a determined effort to develop the economy, particularly through industrialization and the expansion of the tourist industry. One of the pre-conditions of any development was a thorough reform of the whole educational system. 'Thus the Government's educational development programme was designed, not only as a social service providing the intellectual, moral and spiritual training of children for adult life, but also as an important part of an imaginative programme designed to lift the Maltese economy from its depressed state and increase the standard of living of her people.

It is clear from the very start that since the development of technical education was going to take some years, something must be done immediately to provide some sort of technical and industrial training for the unemployed-from whose ranks so many of the juvenile delinquents emerge-for prospective emigrants and to provide sufficient qualified technicians to carry out the five-year development programme.

With the co-operation of the International Labour Organization, which provided the technical advice and technical teachers and supervisors, and also the British Government, which provided a special grant of $£ 400,000$ out of the Colonial Development and Welfare Fund in addition to other funds, the Maltese Government started training courses in January 1956. An old tram depot was taken over and adapted, and since then a classroom block and new workshops have been added, with further accommodation being provided on the sister island of Gozo.

The original six-months course has been extended to ten months, and in the case of lads between sixteen and eighteen it is now being further extended to three years, to enable the boys to sit for examinations of a recognized high standard. Attendance is full-time, and an attendance allowance ranging between $30 s$. and $50 \mathrm{~s}$. a week is being paid. The training includes the teaching of theory and practice of each trade; in addition, English is taught.

The centres have already turned out 300 trainees. including a very valuable 150 electrical wiremen who were immediately absorbed by Government departments and private contractors on the change. over of the electricity distribution system-a project originally scheduled to take more than four years, 
but now in process of being speeded up to be completed by the end of 1958. Most of the trainees have obtained good employment in Malta, or have emigrated.

At present there are 325 young men receiving fulltime training in the following trades :

\begin{tabular}{|l|c|c|c|}
\hline \multicolumn{1}{|c|}{ Course } & Malta & Gozo & Total \\
\hline Woodwork & 45 & 24 & 69 \\
Motor urechanics & 45 & 15 & 60 \\
Electrieal installation & 98 & - & 98 \\
Plumbing & 15 & - & 15 \\
Painting & 15 & - & 15 \\
Sheet metal work & 15 & - & 15 \\
Plastering and tile-laying & 13 & - & 13 \\
Fitting and machining & 10 & - & 10 \\
Concrete supervisors & 10 & -39 & 325 \\
& 286 & 39 & \\
& & &
\end{tabular}

Other courses are shortly being started for the training of agricultural workers and for women in homecraft, hotel duties, handicrafts, etc. In addition, a new scheme is being devised, in collaboration with the British Ministry of Labour, for the further practical training of trainees in factories in the United Kingdom.

Thus it can be seen that the whole of the Government education programme is designed to meet the economic requirements of the Islands, while providing for the individual and social development of young people, so that they can lead a fuller and richer life, either in Malta or overseas. The industrial training courses have given new hope to the youths who received only a bare primary education and then joined the ranks of the unemployed (and often became juvenile delinquents); as secondary education is developed, fewer youths will find themselves in the position in which the young men now enjoying these training courses were once placed : the position of being half-educated, unemployed or unemployable, frustrated and without any aim in life.

\section{INTERNATIONAL CONGRESS OF PSYCHOLOGY}

$\mathrm{T}$

HE fifteenth International Congress of Psychology was held at Brussels during July 27August 3, under the patronage of King Baudouin of the Belgians. The Congress was organized by the Belgian Society of Psychology under the auspices of the International Union of Scientific Psychology founded in 1951 at the thirteenth Congress, held at Stockholm. 'The Union has consultative status with Unesco, and now represents twenty-six national psychological societies. More than a thousand persons attended the Congress from some thirty countries, including about two hundred from the United States and many representatives from the U.S.S.R., Poland, Hungary, Czechoslovakia and Rumania. The homogeneity of the assembly was tempered by a sprinkling of neurologists, psychiatrists, physiologists, etho. logists, educationists and philosophers.

Inaugural addresses were given by M. Léo Collard, the Belgian Minister of Education, Prof. Jean Piaget, president of the International Union of Scientific Psychology, Prof. Otto Klineberg, secretary-general of the Union, Prof. Albert Michotte, president of the Congress, and by Prof. Henri Piéron, of the Collège de France. These were followed by Prof. Michotte's presidential address, "Reflexions on the Role of Language in the Analysis of Perceptual Organization", in which he emphasized the importance of distinguishing, first, the verbal report given by an experimental subject; second, the experimenter's interpretation of this report; and third, the theoretical construction which the experimenter places upon his own interpretation. The relevance of this threefold distinction was illustrated by reference to Prof. Michotte's classical experiments on the 'pere ception of causality'. Evening discourses were delivered by Prof. Wolfgang Köhler on "Psychologiund Naturwissenschaft", by Prof. Jean Piaget on "The Role of Models of Equilibrium in Psychological Explanation", and by Prof. Clyde Kluckhohn on "Psychology and Anthropology".

The programme consisted of symposia, individual papers and colloquia on some twenty-six themes. These included such traditional topics as phenomenology, the measurement of sensation, perception, learning, thought, emotion and conflict, motivation, the experience of space and time, biochemical influences on behaviour, brain and mind, and problems of psychological linguistics. The march of time-even in psychology-was recorded by the inclusion of such topics as non-parametric structural analysis, information theory and its psychological applications, and automation. Individual papers covered an even wider territory ranging from "The Impact of Education on Non-Scientific Beliefs in Ethiopia" to "Phantom Limbs". The three colloquia, to which selected participants were invited, were concerned respectively with the training of psychologists, terminology and co-operation with neuropsychiatrists. Psychologists from universities and research and other establishments in Great Britain contributed their fair share to the proceedings. They took part in fifteen out of the twenty-four symposia and were responsible for organizing six of them.

Informal discussions between individual members of a congress can be at least as stimulating as listening to formal lectures, and apart from such informal discussions, there were opportunities for planning and co-ordinating new research. The meeting at Brussels made possible a multitude of invaluable exchanges of this kind and, of course, many new scientific contacts were established. One noticed particularly the keen mutual interest which psychologists from the United States and the U.S.S.R. expressed in work in their respective countries. Unfortunately, many American psychologists, especially those working in military establishments, do not seem to be in a position to propose making professional visits to research institutions in the U.S.S.R. A Russian suggested that they might overcome their difficulties by going as tourists.

It would be an invidious as well as an impossible task to single out the most noteworthy contributions, and I shall not here betray my own bias. Although the old 'schools of psychology' seem to be more or less extinct, psychologists are still sharply divided in the basic conception of their subject as well as in the nature of their work. Nevertheless, anyone with sufficiently broad interests could have profited from participation in most or even all the symposia. No epoch-making discoveries or Copernican revolutions appear to have been announced. Psychologists nowadays seem to be mostly content with modestly describing their day-to-day research, though some are wedded to theories of their own construction and 